\title{
Tetraploid Perennial Teosinte Seed Dormancy and Germination
}

\author{
MARGARITA MONDRUS-ENGLE
}

\section{Abstract}

Tetraploid perennial teosinte is an endangered Mexican relative of maize with potential for use as a tropical rangeland and permanent pasture forage. Seeds are dormant when harvested, becoming more germinable as they afterripen. New-seed dormancy may be broken by pre-soaking seed in a gibberellic acid solution. Other pre-treatments are less effective or inhibit germination. Seeds enclosed in white fruitcases are less germinable than those in dark fruitcases, and frequently lack developed embryos.

\section{Resumen en Espanol}

El teosinite tetraploide perenne es una gramínea rara, indígena a México y afín al maíz, que se puede utilizar en los pastizales y pastos permanentes tropicales. Las semillas están en estado durmiente al cosechar, y aumenta la germinación después de un período de maduración. El período durmiente de las semillas se puede terminar por medio de remojarlas en una solución del ácido giberélico. Otros medidas de terminar el periodo durmiente son menos efectivas o impiden la germinación. Las semillas blancas son menos capaz de germinar que las de color oscur, y frecuentemente carecen del embrión.

Teosinte is the closest known relative of maize (Zea mays L.) and hybridizes freely with maize. Three species of teosinte are recognized. The annual species (Zea mexicana (Schrad.) Reeves and Mangelsdorf) occurs throughout much of Mexico and Guatemala, and is cultivated as a forage crop in India and a few other tropical and subtropical regions (Bogdan 1977). A diploid perennial species (Zea diploperennis) has recently been discovered near Ciudad Guzmán, Jalisco (Iltis et al. 1979), and is considered to have great potential in maize-improvement programs, including the potential for development of perennial maize. The tetraploid perennial species of teosinte (Zea perennis (Hitch.) Reeves and Mangelsdorf) was discovered near Ciudad Guzmán in 1910 (Hitchcock 1922), and live plants were collected by Collins and Kempton (Collins 1921) at the type locality. Perennial teosinte was not observed again in wild colonies until 1977 and was believed extinct in the wild. Guzmán Mejía (1978) rediscovered the species in a few small colonies on Nevada de Colima Volcana near Ciudad Guzmán in 1977. Because wild colonies are small and scattered, Zea perennis is included on Mexico's endangered species list.

All species of teosinte closely resemble maize, with staminate flowers borne in tassels and pistillate flowers in axillary spikes (Fig. 1). Teosinte has survived as a wild plant because the pistillate spike breaks up at maturity to disperse the kernels, which unlike maize kernels, are protected in heavy cellulose-lignin structures called "fruitcases" (Figs. 2-3). Fruitcases are composed of hard segments of the rachis of the spike, and lignified outer glumes (Beadle 1977), and may be black, gray with black speckles, or ivory white. The

The author is assistant professor, California Statc Polytechnic University, Plant and Soil Science Department, 3801 W. Temple Avenue, Pomona, California 91768.

The author is gratelul to Dr. Victor Youngner, University of California, Botany and Plant Science Department, for reviewing the manuscript; and to Dr. G.W. Beadle and the Tall Timbers Research Station for providing seeds. Special thanks are due Rafael Guzmán Mejía and Professor Luz Ma. Villareal de Puga of the Instituto de Botánica, University of Guadalajara, for their invaluable assistance.

Manuscript recevied July 27, 1979.

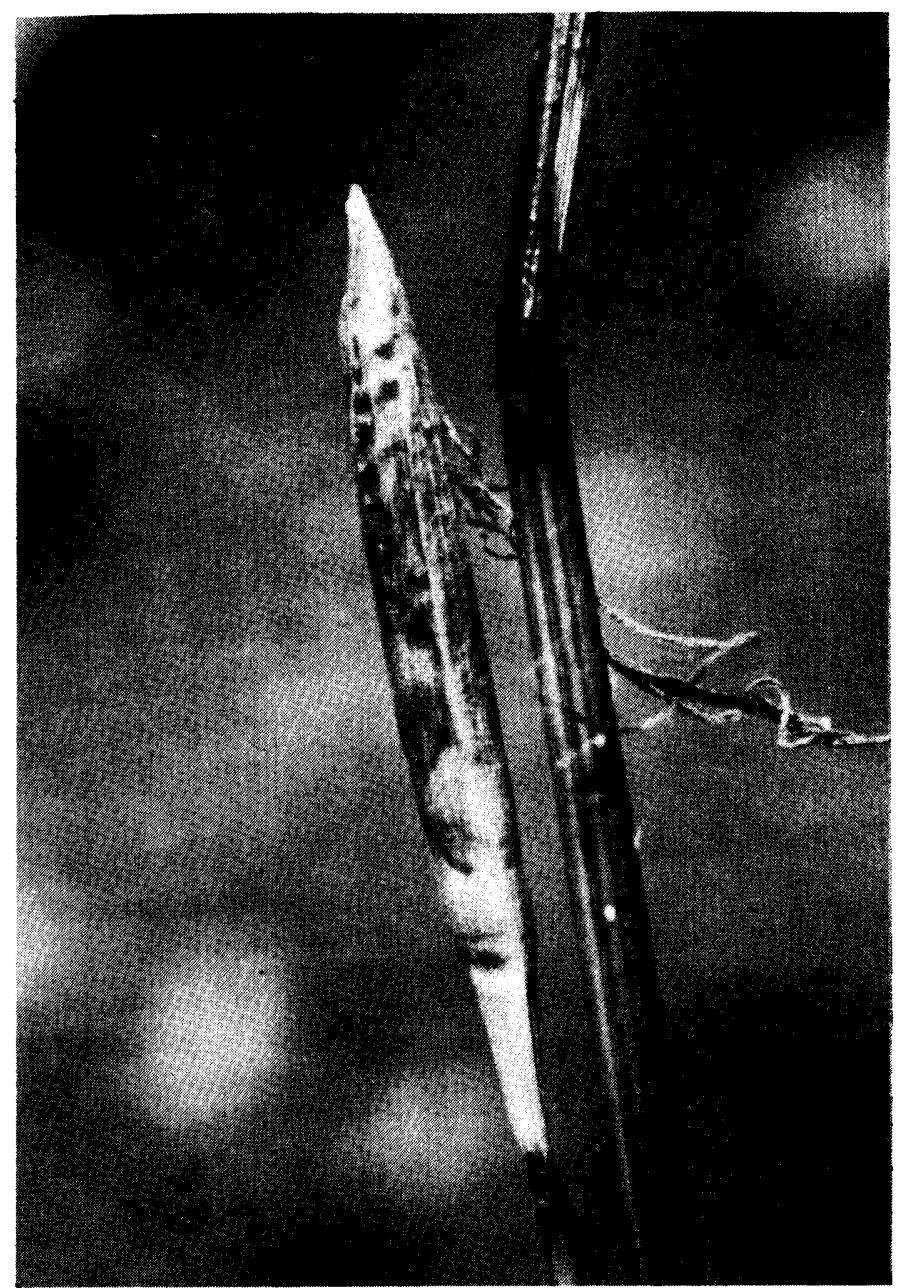

Fig. 1. Female spike enclosed by husks.

perennial species of teosinte are rhizomatous. Annual and tetraploid perennial teosintes are photoperiodic short-day plants (Emerson 1924).

Clones of the Collins and Kempton collection have been maintained since 1920 by rhizome propagation at a number of research institutions. The author collected seeds from wild plants growing on the lower slopes of Nevado de Colima in December 1978. Potted specimens of the Collins and Kempton clone are maintained in a greenhouse. Both perennial species of teosinte show considerable potential for rangeland, permanent pasture, and silage use in the tropics.

Tetraploid perennial teosinte is readily propagated by rhizomes, and regrowth after repeated cutting is persistent. Unlike many perennial tropical forage grasses, teosinte reproduces sexually and could be improved through breeding techniques developed for maize. 


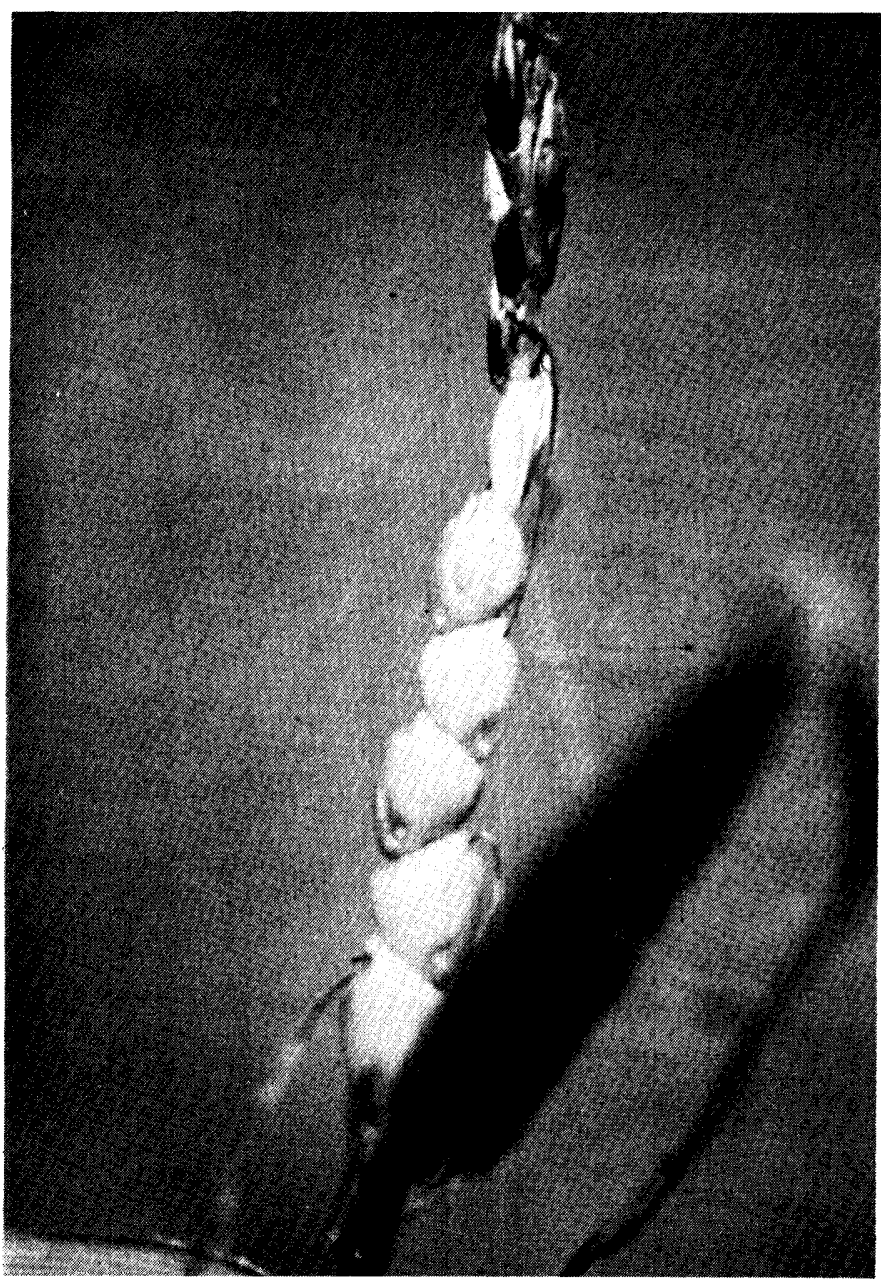

Fig. 2. Female spike with husks removed.

Propagation of perennial teosinte from seeds has been very limited, and seed germination studies have not been previously reported. Wilkes (1967) stated that annual teosinte seeds are not dormant when harvested and germinate readily. Beadle (1977), on the other hand, cited unpublished evidence that annual teosinte seeds are dormant when harvested and require an afterripening period. This study was initiated to determine whether tetraploid

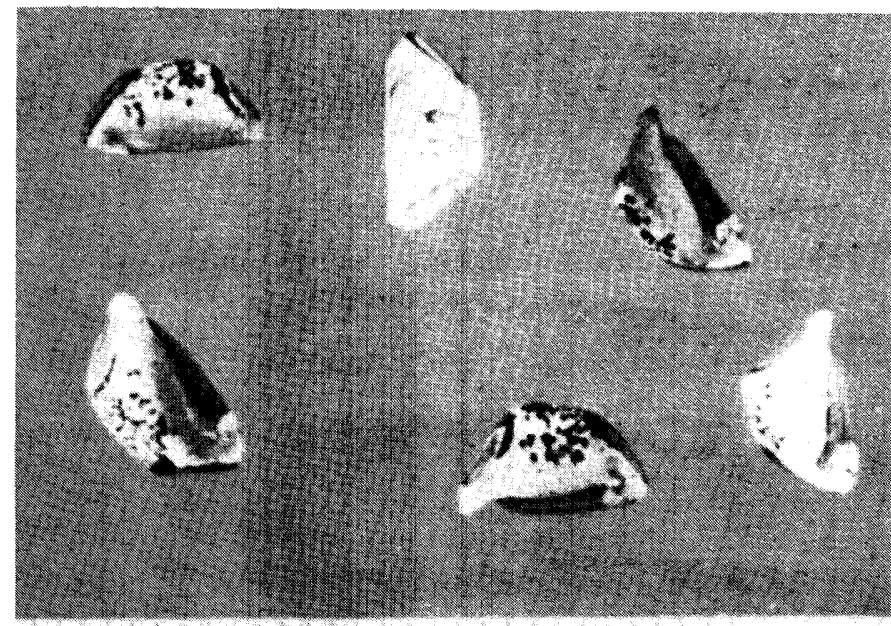

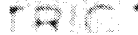

Fig. 3. Seeds enclosed in fruitcases. perennial teosinte seeds are dormant when harvested, and to determine the effects of various pre-treatments upon dormancy. Comparisons of germination of dark and ivory white seeds were also made.

\section{Materials and Methods}

Seeds harvested in 1971 from clones of the Collins and Kempton collection were obtained from the Tall Timbers Research Station in Florida. A mixture of 1974 and 1975 Collins and Kempton seeds was obtained from G.W. Beadle at the University of Chicago. Seeds from wild tetraploid plants were harvested by hand in December 1978, at about 2,000 m elevation on Nevado de Colima. Seeds used for this study were collected from plants approximately $2.5 \mathrm{~m}$ tall, growing at the margin of peach orchards. Seeds from many plants were composited in a single collection, consisting of both dark and unshrivelled ivory white seeds. A tetrazolium test of white 1978 seeds, based on the tetrazolium test for maize (Leveck 1962 ), indicated that $30 \%$ of the white 1978 seeds were viable. However, germination tests indicated considerably lower germinability. White seeds from other years were not available.

An experiment was designed to determine whether perennial teosinte seeds require an afterripening period before germination will occur, and whether dark and white seeds are equally germinable. One month after harvest of wild seeds, a germination trial using 1971, 1974-75, dark 1978 and white 1978 seeds was initiated. Four replications of 10 seeds each were germinated on moist filter paper in covered petri plates. The small size of replicates is justified by the rarity and endangered status of the species. Petri plates were placed in a dark germination cabinet at $20^{\circ} \mathrm{C}$. Germination counts were made twice weekly for 3 weeks. Seeds were considered to have germinated when the radicle had emerged $1 \mathrm{~cm}$. After the 3-week period seedlings were successfully transplanted to soil.

When data indicating dormancy in 1978 seeds were obtained, a second experiment was initiated to determine whether dormancy could be broken by mechanical scarification, gibberellic acid treatment, or repeated washing and soaking in water. Four replications of 10 dark 1978 seeds each were subjected to the following pretreatment: scarification of the fruitcase in a mechanical scarifier; removal of the fruitcase by mechanical scarification; soaking in water for 48 hours, with repeated rinsing to remove any soluble germination inhibitors; soaking in a $500 \mathrm{ppm}$ gibberellic acid solution; soaking in a $1,000 \mathrm{ppm}$ gibberellic acid solution for 24 hours. Seeds receiving no pre-treatment served as a control. All treatments were germinated in petri plates in a dark germinator, and counts were made twice weekly for 3 weeks.

Results of both experiments were analyzed using a completely randomized ANOVA and Duncan's new multiple range test.

\section{Results and Dicussion}

New-seed dormancy was demonstrated for tetraploid perennial teosinte. Although the length of afterripening period required has not yet been determined, experiments indicated that 3 to 7 -year-old seeds are more germinable than freshly harvested ones. Three-and four-year old seeds were more germinable than 7-year-old seeds (Table 1).

Germination of dormant 1978 perennial teosinte seeds was enhanced by pre-treatment with gibberellic acid (Table 2). A 500 ppm gibberellic acid solution increased germination of 1978 seed

Table 1. Germination (\%) of Zea perennis seed harvested during 1971, 1974-75, 1978.

\begin{tabular}{lc}
\hline Year of harvest & Mean \% germination \\
\hline $1974-75$ & $97.5 \mathrm{a}^{1}$ \\
1971 & $60.0 \mathrm{~b}$ \\
1978 (dark) & $20.0 \mathrm{c}$ \\
1978 (white) & $12.5 \mathrm{c}$
\end{tabular}

Means followed by a different letter in the same column are statistically different using Duncan's new multiple range test at the .05 level. 
from $15 \%$ to $52.5 \%$. Pre-treatment in $1,000 \mathrm{ppm}$ gibberellic acid increased germination to $95 \%$, and increased the rate of germination, although less effectively. Mechanical scarification decreased germination both with and without removal of the fruitcase. Fruit case removal greatly increased growth of Rhizopus and Aspergillus niger on seeds.

New-seed dormancy in tetraploid perennial teosinte is apparently due to a natural deficiency of gibberellins. The role of gibberellins in seed germination has been reviewed by McDonough (1977), Mayer and Poljakoff-Mayber (1975), and many others. Gibberellic acid initiates seed germination by derepressing genes stimulating enzyme synthesis (Osborne 1965). Absence of gibberellins is the cause of new-seed dormancy in many species.

The natural cnclosure of teosinte seeds in hard fruitcases does not inhibit germination, and even careful removal of the fruitcase actually decreases germinability. Teosinte fruitcases are unique structures, and have not been studied thoroughly, except from the taxonomic and evolutionary standpoint. Fruitcases apparently serve a protective function in seed germination. Wilkes (1967) noted that seeds of annual teosinte passed intact through the digestive systems of cattle and mules, retaining $90 \%$ viability. The protective value of the fruitcase is apparent under such circumstances, and Wilkes concluded that in some areas considerable distribution of annual teosinte seed in manure occurs.

Mechanical scarification of the outer portion of the fruitcase inhibited germination slightly, and removal of the fruitcase resulted in a 50\% decrcase in germination compared with the control. Mechanical scarification and fruitcase removal may cause physical damage to the enclosed caryopsis, or release of natural gibberellins by the seed may somehow be inhibited.

The slight increase in germination obtained by soaking and washing seeds in water can be explained by increased imbibition, and possibly by the removal of water-soluble germination inhibitors on the seed coat or fruitcase.

Wilkes (1967) noted that ivory white annual teosinte fruitcases do not contain viable seeds. Results of this investigation indicated that at least $12.5 \%$ of unshrivelled white perennial teosinte seeds are developed and germinate without pre-treatment. A tetrazolium test suggested that up to $30 \%$ of white seeds may be viable. However, germination of white seeds pre-treated in gibbcrellic acid was not improved. Only one of ten ivory white seeds receiving a 24hour pre-soak in 1,000 ppm gibberellic acid germinated. White fruitcases are less indurated and can be more easily removed than dark ones. It is evident that the lack of pigment in perennial teosinte fruitcases is closely associated with absence or poor development of embryos.
Table 2. Germination (\%) of Zea perennis seed with and withou pretreatment.

\begin{tabular}{lc}
\hline \hline Pre-treatment & Mean \% germination \\
\hline $1,000 \mathrm{ppm} \mathrm{GA}$ & $95.0 \mathrm{a}^{1}$ \\
$500 \mathrm{ppm} \mathrm{GA}$ & $52.5 \mathrm{~b}$ \\
Water & $30.0 \mathrm{c}$ \\
Control (no pre-treatment) & $15.0 \mathrm{~cd}$ \\
Scarification, fruitcase not removed & $12.5 \mathrm{~cd}$ \\
Scarification, fruitcase removed & $7.5 \mathrm{~d}$ \\
\hline
\end{tabular}

${ }^{1}$ Means followed by a different letter in the same column are statistically different using Duncan's new multiple range test at the .05 level.

\section{Conclusions}

Tetraploid perennial teosinte seeds are dormant when harvested. Germination can remain as high as $97.5 \% 3$ to 4 years after harvest, and $60 \% 7$ years after harvest. New-seed dormancy is effectively broken by pre-soaking in a solution of gibberellic acid. Mechanical scarification and removal of the fruitcase inhibit germination. Pre-soaking in water tends to increase germination to some extent. Although some seeds enclosed in unshrivelled ivory white fruitcases are capable of germinating, most are either unpollinated or poorly developed.

\section{Literature Cited}

Beadle, G.W. 1977. The origin of Zea mays, p. 23-43 in Reed, C.A., Ed. Origins of Agriculture. $1013 \mathrm{p}$.

Bogdan, A.V. 1977. Tropical pasture and fodder plants. Longman, London. $475 \mathrm{p}$.

Collins, G.N. 1921. Teosinte in Mexico. J. Hered. 12:339-350.

Emerson, R.A. 1924. Control of flowering in teosinte. J. Hered. 15:41-48.

Guzmán Mejía, R. 1978. Redescubrimiento de Zea perennis (Gramineae) Phytologia 38:177.

Hitchcock, A.S. 1922. A perennial species of teosinte. J. Wash. Acad. Sci. 12:205-208.

Iltis, H., J.F. Doebley, R. Guzmán Mejia, and B. Pazy. 1979. Zea diploperennis (Gramineae), a new Mexican diploid perennial teosinte. Science 203:186-187.

Leveck, H.E. 1962. The tetrazolium test for seed viability. Miss. Ag. Exp. Sta. Tech. Bull. 51.62 p.

Mayer, A.M., and A. Poljak off-Mayber, 1975. The Germination of Seeds. Pergamon Press, Oxford. 192 p.

McDonough, W.T. 1977. p. 155-184 In: R.E. Sosebee, ed., Rangeland Plant Physiology. Soc. for Range Manage., Denver. 290 p.

Osborne, D.J. 1965. Interactions of hormonal substances in the growth and development of plants. Sci. Food Agr. 16:1-13.

CHANGE OF ADDRESS notices should be sent to the Managing Editor, 2760 West Fifth Ave., Denver, Colo. 80204, no later than the first day of the month of issue. Copies lost due to change of address cannot be replaced unless adequate notice is given. To assure uninterrupted service, provide your local postmaster with a Change of Address Order (POD Form 3575) indicating thereon to guarantee forwarding postage for second-class mail. 